\title{
Impacts of bottom trawling on deep-coral ecosystems of seamounts are long-lasting
}

\author{
F. Althaus ${ }^{1}$, A. Williams ${ }^{1, *}$, T. A. Schlacher ${ }^{2}$, R. J. Kloser ${ }^{1}$, M. A. Green ${ }^{1}$, \\ B. A. Barker ${ }^{1}$, N. J. Bax ${ }^{1}$, P. Brodie ${ }^{1}$, M. A. Schlacher-Hoenlinger ${ }^{2,3}$ \\ ${ }^{1}$ CSIRO Wealth from Oceans Flagship, CSIRO Marine and Atmospheric Research, Castray Esplanade, Hobart, \\ Tasmania 7001, Australia
}

${ }^{2}$ Faculty of Science, Health \& Education, University of the Sunshine Coast, Maroochydore DC, Queensland 4558, Australia ${ }^{3}$ Biodiversity Program, Queensland Museum, PO Box 3300, South Brisbane, Queensland 4101, Australia

\begin{abstract}
Complex biogenic habitats formed by corals are important components of the megabenthos of seamounts, but their fragility makes them susceptible to damage by bottom trawling. Here we examine changes to stony corals and associated megabenthic assemblages on seamounts off Tasmania (Australia) with different histories of bottom-contact trawling by analysing 64504 video frames (25 seamounts) and 704 high-resolution images ( 7 seamounts). Trawling had a dramatic impact on the seamount benthos: (1) bottom cover of the matrix-forming stony coral Solenosmilia variabilis was reduced by 2 orders of magnitude; (2) loss of coral habitat translated into 3-fold declines in richness, diversity and density of other megabenthos; and (3) megabenthos assemblage structures diverged widely between trawled and untrawled seamounts. On seamounts where trawling had been reduced to $<5 \%$ a decade ago and ceased completely $5 \mathrm{yr}$ ago, there was no clear signal of recovery of the megabenthos; communities remained impoverished comprising fewer species at reduced densities. Differences in community structure in the trawled (as compared to the untrawled) seamounts were attributed to resistant species that survived initial impacts, others protected in natural refugia and early colonisers. Long-term persistence of trawling impacts on deep-water corals is consistent with their biological traits (e.g. slow growth rates, fragility) that make them particularly vulnerable. Because recovery on seamounts will be slow, the benefits from fishery closures may not be immediately recognisable or measureable. Spatial closures are crucial conservation instruments, but will require long-term commitments and expectations of performance whose time frames match the biological tempo in the deep sea.
\end{abstract}

KEY WORDS: Trawling impacts $\cdot$ Seamounts $\cdot$ Deep-sea corals $\cdot$ Recovery $\cdot$ Conservation $\cdot$ Fishing

\section{INTRODUCTION}

In the vast and mostly flat, muddy expanses of the deep sea, seamounts provide raised and exposed habitat where hydrodynamic energy can be focused and secondary biological productivity may be enhanced (McClain 2007). Seamounts (as defined by Pitcher et al. 2007) are elevated seafloor structures, mostly formed by volcanism (Wessel 2007), that are numerous (e.g. >30000 in the Pacific Ocean, Smith \& Jordan 1988), but mostly small in area (e.g. $<20 \mathrm{~km}^{2}$ for $\sim 800$ around New Zealand, Rowden et al. 2005). They create favourable habitats for sessile suspension feeders where accelerated water flows deliver food and winnow sediment from the rocky seafloor (Genin et al. 1986, Genin 2004).

Scleractinian, antipatharian and gorgonian corals are an abundant and species-rich component of the seamount megabenthos (Rogers et al. 2007, Mortensen et al. 2008) amongst which colonial or pseudo-colonial stony corals can form complex, reef-like structures which are habitats for a variety of other fauna (Henry \& 
Roberts 2007). Patchy thickets of the scleractinian coral Solenosmilia variabilis, a widely distributed species in the southwest Pacific Ocean (Freiwald et al. 2004, Tittensor et al. 2009), can cover large areas on seamounts (Koslow et al. 2001, Clark \& Rowden 2009). Coral thickets provide structural habitat for diverse communities of sessile and mobile fauna (Reed et al. 2007, Rogers et al. 2007, Mortensen et al. 2008), including distinct assemblages of some groups (e.g. ophiuroids, O'Hara et al. 2008).

Several benthopelagic fish species aggregate for spawning or feeding over seamounts (Genin et al. 1988, Rogers 1994, Clark 2001). Schools of these fish have increasingly become the target of commercial bottom-contact trawling during the last 3 decades as fishing fleets move from declining, traditional, shelfbased fisheries to exploit less accessible populations further offshore (Koslow et al. 2000). The high commercial value of species such as orange roughy (Clark 2001) and advances in fishing gear technology (Clark \& Koslow 2007) have sustained this effort. While the spatial extent of trawl impact may be small in absolute terms, it is often intensive with 100s to 1000s of individual trawl tows concentrated on individual seamounts (Koslow et al. 2001, Clark \& O'Driscoll 2003). Such hotspots of seamount trawling may also be dispersed over wide areas, for example in the North Atlantic (Hall-Spencer et al. 2002) and southwest Pacific (Clark \& O'Driscoll 2003). In these basins, and elsewhere, seamount fisheries have been characterised by rapid and sequential 'fish-downs' to economic extinction on individual features (Koslow et al. 2000, Bax et al. 2005, Clark \& Koslow 2007).

Bottom trawling on seamounts significantly impacts habitats and fauna (Clark \& Koslow 2007, Mortensen et al. 2008). For example, trawl catches from a developing fishery on seamounts of the South Tasman Rise contained high levels of bycatch (Anderson \& Clark 2003). One to 15 tonnes of bycatch were taken in many individual trawls; in the 1997-1998 season, this bycatch exceeded the total catch weight of the target fish (Oreosomatidae; Anderson \& Clark 2003). The stony coral Solenosmilia variabilis dominated the bycatch, which also comprised many other invertebrates (mostly species of antipatharian, alcyonacean and other scleractinian corals) and fishes. Similarly, Probert et al. (1997) found that corals made up high proportions of the megabenthos bycatch in commercial trawling off New Zealand. Thus trawling not only removes living fauna (Koslow et al. 2001, Hall-Spencer et al. 2002) but also clears the accumulated biogenic substratum (Watling \& Norse 1998), which can be important as the base for settlement of new coral colonies on seamounts (Andrews et al. 2002) and as habitat for a variety of other sessile and mobile seamount-associated species ( $\mathrm{O}^{\prime}$ Hara et al. 2008).
Compared to their shallow-water counterparts, deep benthic megafauna are less resilient to physical impacts (Kaiser et al. 2002, Mortensen et al. 2005), often being very slow-growing and long-lived (Samadi et al. 2007). These biological traits, which make deep megabenthic species highly vulnerable to trawl damage, are exemplified by corals, whose hard skeletons permit reliable age and growth estimates to be made. Estimates from a variety of deepwater locations have consistently found that individual colonies live 10 s to 100 s of years and grow at a rate of only millimetres per year (Tracey et al. 2007, Roark et al. 2006, Sherwood et al. 2006). These findings indicate that recovery of deep-coral ecosystems on seamounts may be very slow.

A seminal study of fishing impacts on Tasmanian seamounts conducted in January 1997 (Koslow et al. 2001) documented the direct, detrimental effects of bottom trawling for orange roughy on the seamount megabenthos. All seamounts with shallow peaks ( 700 to $1000 \mathrm{~m}$ depth) examined by Koslow et al. (2001) had evidence of fishing impacts that extended from the peak to at least $\sim 1300 \mathrm{~m}$. Here, the coral matrix formed by Solenosmilia variabilis and the associated megabenthos had been extensively removed. Seamounts with deep peaks $(\sim>1100 \mathrm{~m})$ were believed to have been either little fished or unfished because they did not support aggregations of orange roughy. The preliminary results of this survey work led to the establishment of the Tasmanian Seamounts Marine Reserve in 1997, which included several deep seamounts (with peak depths of $>1100 \mathrm{~m}$ ) and excluded bottom-contact fishing (Koslow et al. 2001). Shortly after this reserve was established, stock declines led to a distinct reduction in fishing effort on many seamounts which were not protected. More recently, the declaration of 2 additional and larger Commonwealth Marine Reserves (Huon and Tasman Fracture) has permanently excluded bottom trawling from the majority of seamounts in this region (DEWHA, www.environment.gov.au/coasts/mpa/southeast/index.html).

In the present study, we evaluate the impact of trawling on the composition and diversity of seamount megabenthos by comparing seamounts with documented and contrasting fishing histories, and assess whether cessation of fishing on one seamount in the last 5 to $10 \mathrm{yr}$ has had a measurable effect on the megabenthos. This work differs from Koslow et al. (2001) in 3 important aspects. (1) Advances in navigation, mapping and photographic technology has enabled targeted collection of geo-referenced, quantitative image data. (2) Our comparison of trawled with untrawled seamounts is within a common depth range $(1100$ to $1400 \mathrm{~m})$; therefore, it is not confounded by depth. (3) The dramatic reduction of trawling during the last $\sim 10$ yr on a seamount that had previously been 
heavily trawled provides us with the opportunity to evaluate changes in the megabenthos in the context of recovery from trawling impacts.

\section{MATERIALS AND METHODS}

Field data collection. The distribution of habitat types on seamounts in Australian waters south of Tasmania, including areas within and adjacent to the Huon and Tasman Fracture Commonwealth Marine Reserves, was mapped in 2006 (CSIRO FRV 'Southern
Surveyor' Voyage SS200611; Fig. 1a). The tools used were a SIMRAD EM300 $30 \mathrm{kHs} 1 \times 1^{\circ}$ multibeam sonar (MBS) and the CSIRO towed deep camera system (Shortis et al. 2008). A key objective of the survey was to determine distributions of habitat types and benthic megafauna relative to the spatial and temporal distribution of bottom trawl fishing.

The entire seamount field was mapped with the MBS, data gridded into $30 \mathrm{~m}$ resolution cells and a total of 38 camera transects (up to $4.7 \mathrm{~km}$ in length) were run from the peak to base of 25 seamounts (replicates were completed on some): 15 of these seamounts
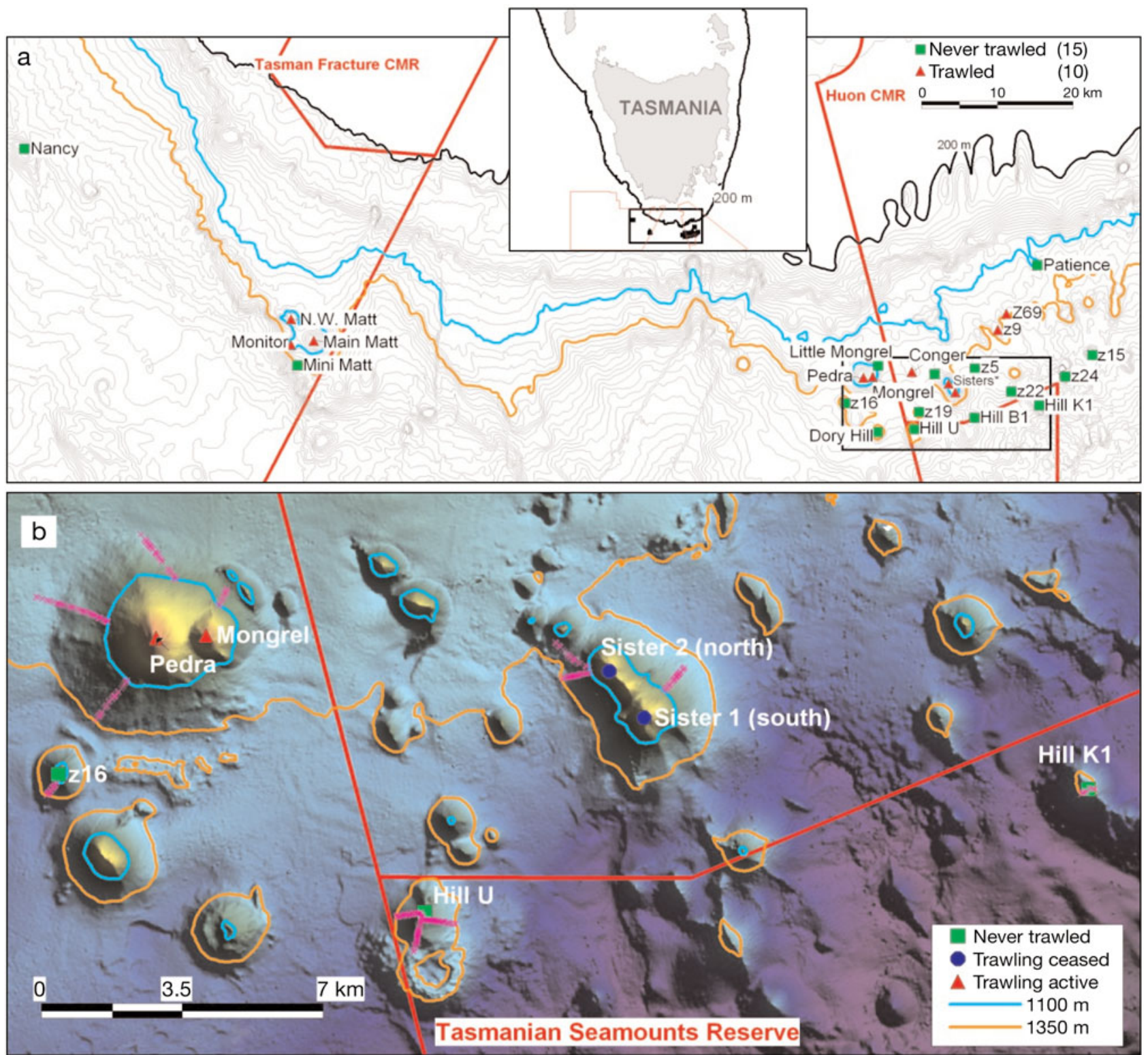

Fig. 1. Location of (a) 25 seamounts off southern Tasmania (Australia) surveyed for habitat properties and megabenthos assemblages using continuous stereo video, and (b) detailed swath bathymetry map ('sun-illuminated' raster)—orange: $\sim 600 \mathrm{~m}$; purple: $\sim 4000 \mathrm{~m}$ depth) of seamounts surveyed in detail with high-resolution still images (pink crosses) to assess changes in megabenthos related to fishing history. Red lines: Australian Commonwealth marine reserves (CMR) 
(19 transects) had never been trawled ('never trawled'), whereas 10 seamounts (19 transects) had been exposed to some degree of fishing with bottomcontact trawl gear ('trawled'; Fig. 1, Table S1 in Supplement 1, at www.int-res.com/articles/suppl/ m397p279_app.pdf). We assessed the fishing history of individual seamounts using logbook data recorded by the Australian Fisheries Management Authority (AFMA) at $0.01^{\circ}$ resolution. These data supported an earlier assertion (Koslow et al. 2001) that all known seamounts with peaks < 1100 m had been trawled to some extent. Reported trawl depths ranged from $\sim 600$ to $1450 \mathrm{~m}$ (AFMA unpubl. data). Based on logbook data, 3 groups of seamounts were identified for more detailed comparative analysis of seamounts with different fishing histories over the last decade: (1) 'never trawled' - no bottom trawling recorded; (2) 'trawling ceased' - intensive fishing until 1997 (total of 1606 trawls) which decreased to no fishing after 2003 (total of 83 trawls between 1998 and 2003); and (3) 'trawling active' - intensive fishing until 1997 (total 4726 trawls) which continued albeit at a reduced level since then (total of 374 trawls; Fig. 1b, Table 1). Because trawled and never-trawled seamounts often differ in depth, contrasts of ecological variables in relation to fishing effort can become confounded by depth differences. We explicitly corrected for such depth confounding by only using data from the 1100 to $1400 \mathrm{~m}$ depth stratum which is common to both the trawled and untrawled seamounts, part of the core distribution of

Table 1. Depth statistics and sampling effort of still images analysed for changes in megabenthic assemblages in relation to fishing intensity on seamounts (cf. Fig. 1b for location of seamounts and stations)

\begin{tabular}{|lccccr|}
\hline $\begin{array}{l}\text { Seamount } \\
\text { (Station) }\end{array}$ & $\begin{array}{c}\text { Average } \\
\text { depth (m) }\end{array}$ & $\begin{array}{c}\text { Min. } \\
\text { depth (m) }\end{array}$ & $\begin{array}{c}\text { Max. } \\
\text { depth (m) }\end{array}$ & $\begin{array}{c}\text { Start position } \\
\text { (lat }{ }^{\circ} \text { S/long }{ }^{\circ} \text { E) }\end{array}$ & $\begin{array}{c}\text { No. images } \\
\text { analysed }\end{array}$ \\
\hline Never trawled & & & & & \\
z16 (37) & 1230 & 1105 & 1347 & $44.29 / 147.07$ & 38 \\
Hill U (23) & 1232 & 1114 & 1347 & $44.32 / 147.18$ & 55 \\
Hill U (27) & 1201 & 1099 & 1323 & $44.32 / 147.18$ & 80 \\
Hill U (38) & 1211 & 1115 & 1353 & $44.32 / 147.18$ & 77 \\
Hill K1 (30) & 1316 & 1274 & 1352 & $44.29 / 147.39$ & 17 \\
Hill K1 (40) & 1299 & 1248 & 1340 & $44.29 / 147.39$ & 13 \\
& $\bar{X}: 1225$ & min: 1099 & max: 1353 & & $\Sigma: 280$ \\
Trawling ceased & & & & & \\
Sister 1-south (41) & 1192 & 1099 & 1280 & $44.27 / 147.26$ & 83 \\
Sister 2-north (25) & 1249 & 1109 & 1350 & $44.27 / 147.23$ & 51 \\
Sister 2-north (33) & 1236 & 1100 & 1290 & $44.27 / 147.23$ & 41 \\
& $\bar{X}: 1219$ & min: 1099 & max: 1350 & & $\Sigma: 175$ \\
Trawling active & & & & & \\
Pedra (20) & 1213 & 1099 & 1300 & $44.25 / 147.08$ & 85 \\
Pedra (36) & 1212 & 1101 & 1343 & $44.27 / 147.09$ & 45 \\
Mongrel (22) & 1194 & 1098 & 1244 & $44.25 / 147.10$ & 102 \\
Mongrel (43) & 1120 & 1098 & 1127 & $44.25 / 147.12$ & 27 \\
& $\bar{x}: 1196$ & min: 1098 & max: 1343 & & $\Sigma: 259$ \\
\hline
\end{tabular}

the matrix-building stony coral Solenosmilia variabilis and within the range of trawling depths reported to AFMA. We were not aware of other betweenseamount differences in overall terrain type, slope or aspect which may have confounded our comparisons; fine-scale current data for the depth range of interest was not available. Thus we did not consider any of these physical attributes here.

We acquired both continuous video and still images on the seamounts which were used for 2 complementary purposes. First, the continuous video data provided an overview of the distribution of fauna over all seamounts surveyed, contrasted by overall fishing history (i.e. trawled at any time in history versus never trawled). Fauna were scored on video using general categories because resolution was not sufficient to identify individual taxa which were often small or had similar morphology. The general fauna categories were attributed to each video-frame (1 s intervals), as the dominant category in the foreground of the field of view (lower third of the screen) - this avoided overlaps between consecutive scored frames. Second, the high-resolution still images were used for a detailed analysis of megabenthos assemblages on the 3 seamount groups with different fishing histories over the last decade (Table 1). These were collected at intervals of $\sim 10 \mathrm{~s}$. Because individual images were separated in real space along transect lines (mean distance $=15 \mathrm{~m}$ ), they were not contiguous and could therefore be treated as individual sampling units in the analysis. The greater resolution of the still images enabled detailed counts of identifiable taxa where individuals as small as $1 \mathrm{~cm}$ could be consistently recognised. The stereo configuration of the video was used to determine absolute areas of seafloor in the high-resolution still images and, thus, translate counts into density estimates within polygons of known area (Shortis et al. 2008).

The deep camera system was towed behind the research vessel on an armoured fibre optic cable at about 1 knot. Real-time video feed was used to adjust the length of the fibre-optic cable to maintain a consistent height off the seabed of about 2 to $4 \mathrm{~m}$. The continuous stereo video images from the deep camera system were recorded with 2 paired 3-CCD PAL video cameras onto digital video tapes. High resolution, 8 megapixel, digital still images of the seafloor 
were taken with a Canon EOS 400D camera at frequent intervals $(\sim 10 \mathrm{~s})$, determined by the strobe recharge time. Both the video cameras and the still camera were mounted obliquely on the camera platform to give an approximate field of view of $5 \mathrm{~m}$ (width) by $5.5 \mathrm{~m}$ (depth of field). The geo-location of the camera platform was accurate within $20 \mathrm{~m}$ by combining the GPS location of the ship with data on distance and direction of the camera platform in relation to the ship from an ultra-short base line (USBL) tracking beacon mounted on the platform and crosschecked with MBS seabed features. Depth of the image data was derived from the detailed swath bathymetry at the camera location.

Image analyses. A total of 64504 video frames were visually classified for epibenthos types. This analysis encompassed 38178 frames from 15 never-trawled seamounts and 26326 frames from 10 trawled seamounts (including those where trawling is still active and those where it has ceased). Video data covered a depth range of 630 to $1830 \mathrm{~m}$ (Table S1). Since corals and the habitats formed by them are reported as the most abundant and widespread, but equally most vulnerable, faunal component on seamounts (e.g. Koslow et al. 2001, Hall-Spencer et al. 2002, Clark \& O'Driscoll 2003), the following 5 categories of epibenthos types were used to classify video images: (1) bare - no sessile epifauna; (2) non-coral epifauna; (3) Solenosmilia thicket (the 3-dimensional framework built by live colonies and the dead skeletons of the coral S. variabilis); (4) slender unbranched corals mostly a new genus of Chrysogorgiidae (P. Alderslade pers. comm.); and (5) other corals. Each record was visually scored in terms of cover or abundance of the epifaunal type as 'low' (<10\%), 'medium' (10-50\%) or 'high' (>50\%; Williams et al. 2009). The combined fauna and abundance scores were translated into a percent occurrence per $100 \mathrm{~m}$ depth-bin for analysis.

Absolute density measures of 51 epibenthic invertebrate megafauna 'photo-taxa' (as defined below) (Table S2, Fig. S1 in Supplement 2, at www.int-res. com/articles/suppl/m397p279_app.pdf), were recorded from 714 still images from the 3 seamount groups at depths between 1099 and 1353 m (Table 1). Photo-taxa are elements of the fauna which we could consistently identify, including growth forms and/or species of sessile groups such as stony, black, soft and gorgonian corals (orders Scleractinia, Antipatharia and Alcyonacea), sponges, anemones and bryozoans; mobile invertebrate groups comprised echinoderms, decapod crustaceans and molluscs (Table S2). Each photo-taxon was deemed to be consistently reliable, and was validated by K. Gowlett-Holmes and P. Alderslade (CSIRO) based on comparison of images with physical collections of the fauna (A. Williams unpubl. data).
Surface areas in the 3-dimensional perspective of the oblique field of view were calculated from calibrated stereo imagery using Photomeasure software (SeaGIS, www.seagis.com.au/index.html). Polygons of known area were drawn in the images by identifying a series of common points in corresponding frames from the stereo video and the still images. These polygons encompassed an average area of $5.0 \mathrm{~m}^{2}$ (range $=0.4$ to $19.0 \mathrm{~m}^{2}$ ). We counted the number of all individuals within these polygons. In addition, the percent cover of the main biogenic habitat - Solenosmilia thicket (i.e. the intact 3dimensional framework of the coral, including live and dead colonies) - was estimated within the polygon area of each image. The number of snapped-off bases and detached specimens of large colonies of, for example, gorgonians or black corals was also counted.

Data analyses. The species diversity of the seamount epibenthos is described using species richness (number of photo-taxa per image), complemented by Hill's diversity indices. We used Hill's numbers N1 and N2 as diversity indices and the modified Hill's ratio E5 as measure of evenness: E5 = (N2-1)/(N1-1). These indices are derived from the common Shannon $\left(H^{\prime}\right)$ and Simpson $(\lambda)$ indices $\left(\mathrm{N} 1=\mathrm{e}^{H^{\prime}}, \mathrm{N} 2=1 / \lambda\right)$, and can broadly be interpreted in terms of species numbers: N1 measures the number of 'abundant' species and N2 the number of 'very abundant' species (Ludwig \& Reynolds 1988).

We used contrasts among images taken from trawling-active, never-trawled or trawling-ceased seamounts to examine our null hypothesis of no significant difference in epibenthos attributes related to fishing history and intensity. For compound, univariate descriptors of assemblages structure and diversity (e.g. total abundance, diversity and evenness indices), contrasts among the 3 fishing classes were made with Kruskal-Wallis tests; this is the non-parametric equivalent of ANOVA, used here because data were frequently non-normal and heteroscedastic, which could not be remedied by data transformations. Because the presence of coral matrix has frequently been identified as a key driver of epibenthos diversity (Rogers et al. 2007, Mortensen et al. 2008), we compared median values of key faunal attributes between images with and without Solenosmilia thicket across all seamounts using a Mann-Whitney U-test.

Multivariate comparisons (i.e. species composition and their abundance in images) were performed with analysis of similarities (ANOSIM, Clarke 1993), complemented by non-metric multidimensional scaling (NMDS) ordinations (Clarke \& Gorley 2006). All tests were based on Bray-Curtis similarities calculated on square root-transformed density data that were aggregated at the transect scale. The photo-taxa driving the differences between groups were identified by similarity percentage (SIMPER) analysis (Clarke 1993). 
Diagnostic checks. To assess whether multivariate differences in assemblage structure between seamounts of different fishing history were influenced by the mobility of photo-taxa included in the analysis, we used matrix correlations, implemented in the RELATE routine of Primer (Clarke \& Gorley 2006). The matrix correlation between the similarity matrix based on data including all megabenthos photo-taxa and matrices based on sessile or mobile photo-taxa only were strong (all photo-taxa versus sessile only, Rho $=0.984$, $\mathrm{p}<0.001$; all photo-taxa versus mobile only, Rho = 0.731, $\mathrm{p}<0.001$ ), showing that choice of group did not overly influence relationships between and among transects. Similarly, ANOSIM analyses comparing assemblages between different fishing histories yielded highly similar results for mobile and sessile photo-taxa combined $(\mathrm{R}=0.932)$ and sessile phototaxa only $(\mathrm{R}=0.952)$; assemblages of mobile phototaxa were less dissimilar between fishing classes $(\mathrm{R}=$ 0.608).

Choice of data transformation also did not affect the multivariate patterns of dissimilarity nor the ANOSIM results. Matrix correlations were high between the similarity matrix based on square root-transformed data (as used in the analyses) and matrices derived from raw density data (Rho $=0.92, \mathrm{p}<0.001)$; 4 th-root transformed data (Rho $=0.929, \mathrm{p}<0.001)$; logtransformed data (Rho $=0.952, \mathrm{p}<0.001)$; and presence/absence data (Rho $=0.652, \mathrm{p}<0.001)$. ANOSIM R-values were similarly high for all transformations $(R>0.81)$, except the presence/absence data $(R=0.48)$.

\section{RESULTS}

\section{Coral and megabenthos distribution}

Coral abundance decreased with depth $\left(\mathrm{r}_{\mathrm{S}}=-0.97\right.$, $\mathrm{p}<0.001$ ) on seamounts without trawling, with few individuals recorded below $1600 \mathrm{~m}$. Similarly, noncoral megabenthos of medium/high abundance was more common at shallower depths $\left(\mathrm{r}_{\mathrm{S}}=-0.95, \mathrm{p}<\right.$ 0.001). Conversely, on the same seamounts, bare substrata dominated deeper samples $\left(\mathrm{r}_{\mathrm{S}}=0.91, \mathrm{p}<0.001\right)$, and the frequency of non-coral epibenthos of low abundance also increased with depth $\left(\mathrm{r}_{\mathrm{S}}=0.97, \mathrm{p}<\right.$ 0.001). Thus, in the absence of anthropogenic disturbance, there was a natural decline in the abundance of corals with increasing depth.

Based on the intensive and broad-scale benthic video surveys across 25 seamounts, corals (all scleractinians, antipatharians and alcyonaceans combined) were markedly reduced on seamounts that had been trawled (Fig. 2). In the bathymetric range where video samples overlapped for trawled and never-trawled seamounts (1100 to $1400 \mathrm{~m})$, the faunal assemblages differed substantially in composition and density of broad groups (ANOSIM, R = 0.603, p < 0.001). Differences between trawled and never-trawled seamounts were not only marked in terms of overall fauna cover and coral occurrence, but also in terms of the make-up of the coral assemblage. On never-trawled seamounts, virtually all (89 to $99 \%$ ) records of corals at medium or high cover were Solenosmilia thicket. Conversely, on trawled seamounts, corals were mostly a slender, unbranched new genus of the Chrysogorgiidae family, with the proportion of Solenosmilia thicket significantly lower at 6 to $35 \%$ (Wilcoxon matched pairs test, $\mathrm{W}=36, \mathrm{p}=0.008)$. Where Solenosmilia thicket was observed on trawled seamounts, it was in isolated, small patches (typically $<10 \mathrm{~m}$ linear distance separated by 100 s of $\mathrm{m}$ ).

\section{Trawling impacts on habitat-forming corals}

Trawling caused dramatic changes to the distribution, density and diversity of megabenthos. Analysis of the 3 seamount groups with different fishing histories over the last decade (Table 1) showed that cover of Solenosmilia thicket (as estimated in still images) was reduced by 2 orders of magnitude on seamounts where trawling was still active $(\bar{x}=0.12 \%)$ compared to an average bottom cover of $52 \%$ on never-trawled seamounts (Kruskal-Wallis, $H_{(\mathrm{N}=714)}=400.98, \mathrm{p}<$ 0.001; Fig. 3a). Cover of Solenosmilia thicket remained also very low $(\bar{x}=3 \%)$ on seamounts where trawling had ceased (Fig. 3a). The distribution of Solenosmilia thicket along individual transects (Fig. 4) showed its widespread distribution on never-trawled seamounts, virtual absence where trawling was still active and small patches remaining on seamounts where fishing had effectively ceased in the 5 to $10 \mathrm{yr}$ prior to our survey. In fact, virtually none $(<2 \%)$ of the images from trawled seamounts showed coral thickets and, equally, $79 \%$ of images from seamounts where trawling had ceased had no corals (Fig. 5). The density of snappedoff bases and detached specimens of large colonies of gorgonians and black corals (termed 'broken stems'), assumed to be a sign of mechanical disturbance, was significantly higher $\left(\bar{x}=0.14\right.$ ind. $\left.\mathrm{m}^{-1}\right)$ on trawling active compared with never-trawled $\left(\bar{x}=0.03\right.$ ind. $\left.\mathrm{m}^{-1}\right)$ or trawling-ceased seamounts $\left(\bar{x}=0.01\right.$ ind. $\mathrm{m}^{-1}$; $H_{(\mathrm{N}=714)}=40.94, \mathrm{p}<0.001 ;$ Fig. 3b).

Removal of the Solenosmilia thicket by trawling was associated with significant changes in the entire epibenthos. Areas with Solenosmilia thicket supported about 3 times the density and diversity of other megabenthos compared with areas without the thicket (Table 2). This marked contrast in megabenthos cover 

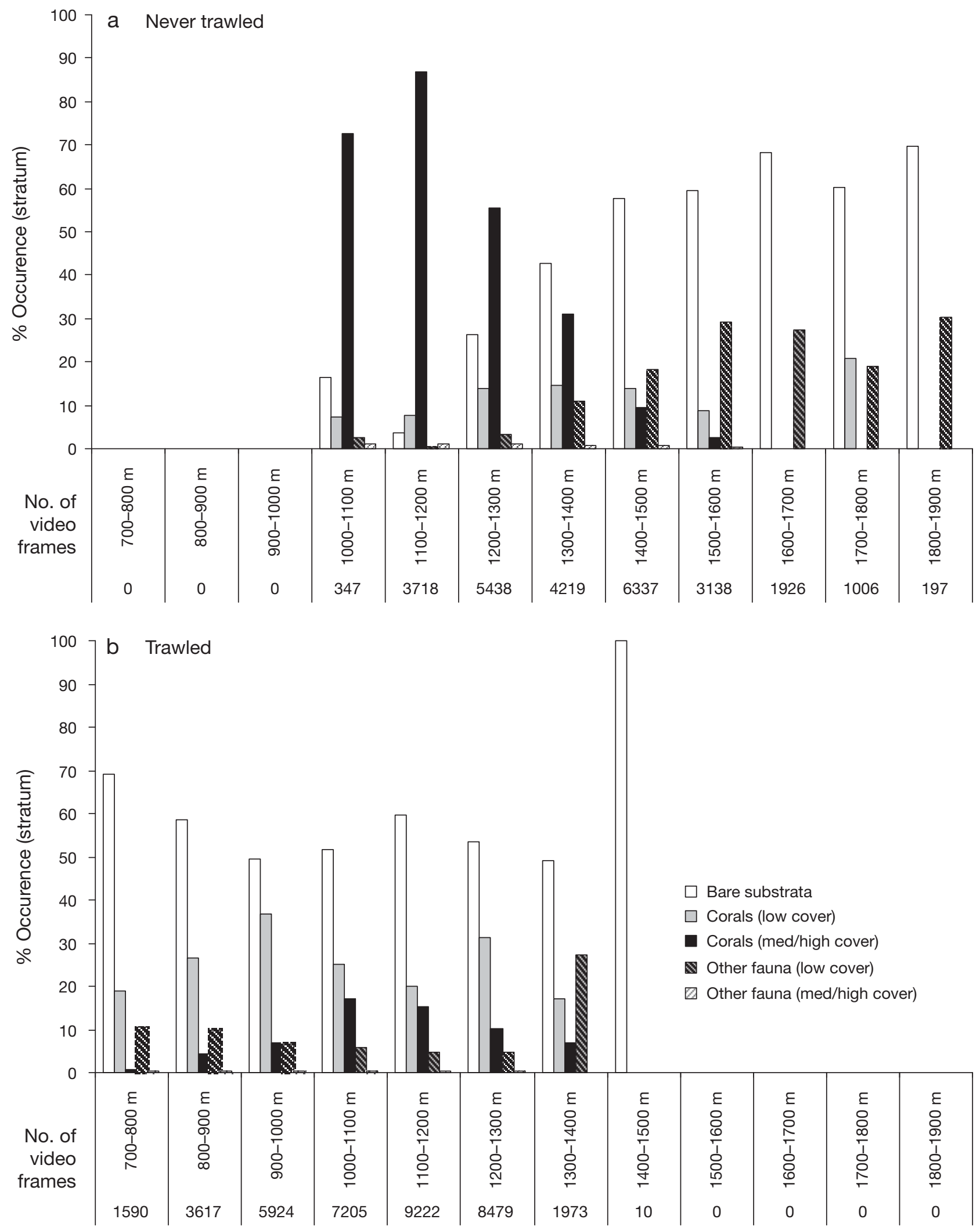

Fig. 2. Occurrence of broad faunal categories and bare substrate on (a) never-trawled and (b) trawled seamounts. Data were derived from visually scoring 26326 frames from 10 trawled seamounts and 38178 frames from 15 untrawled seamounts and summarised into percent occurrence by $100 \mathrm{~m}$ depth-bins 

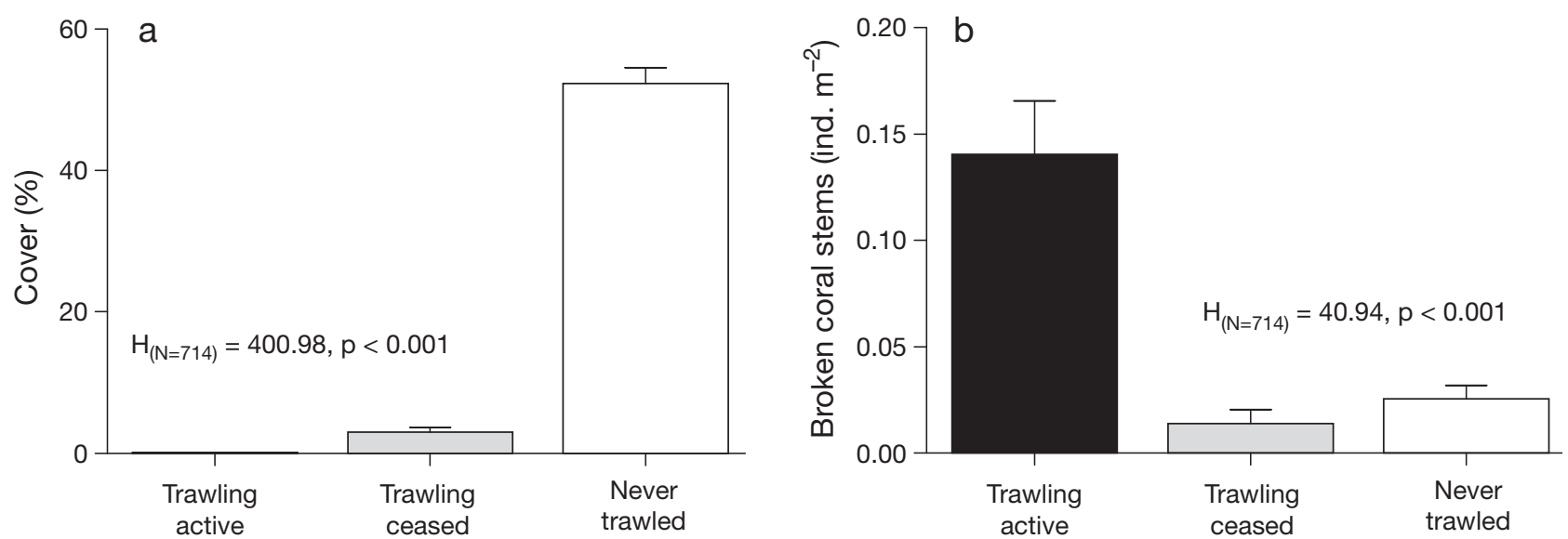

Fig. 3. Comparison of the (a) percent cover of Solenosmilia thicket (biogenic habitat formed by the coral Solenosmilia variabilis) and (b) number of snapped-off bases and detached coral specimens (broken coral stems) per image among seamounts that continue to be actively trawled (black), seamounts where trawling ceased 5 to $10 \mathrm{yr}$ ago (grey) and seamounts which were never trawled (white). Data are mean $+\mathrm{SE}$; all differences between means were significant $(\mathrm{p}<0.01)$
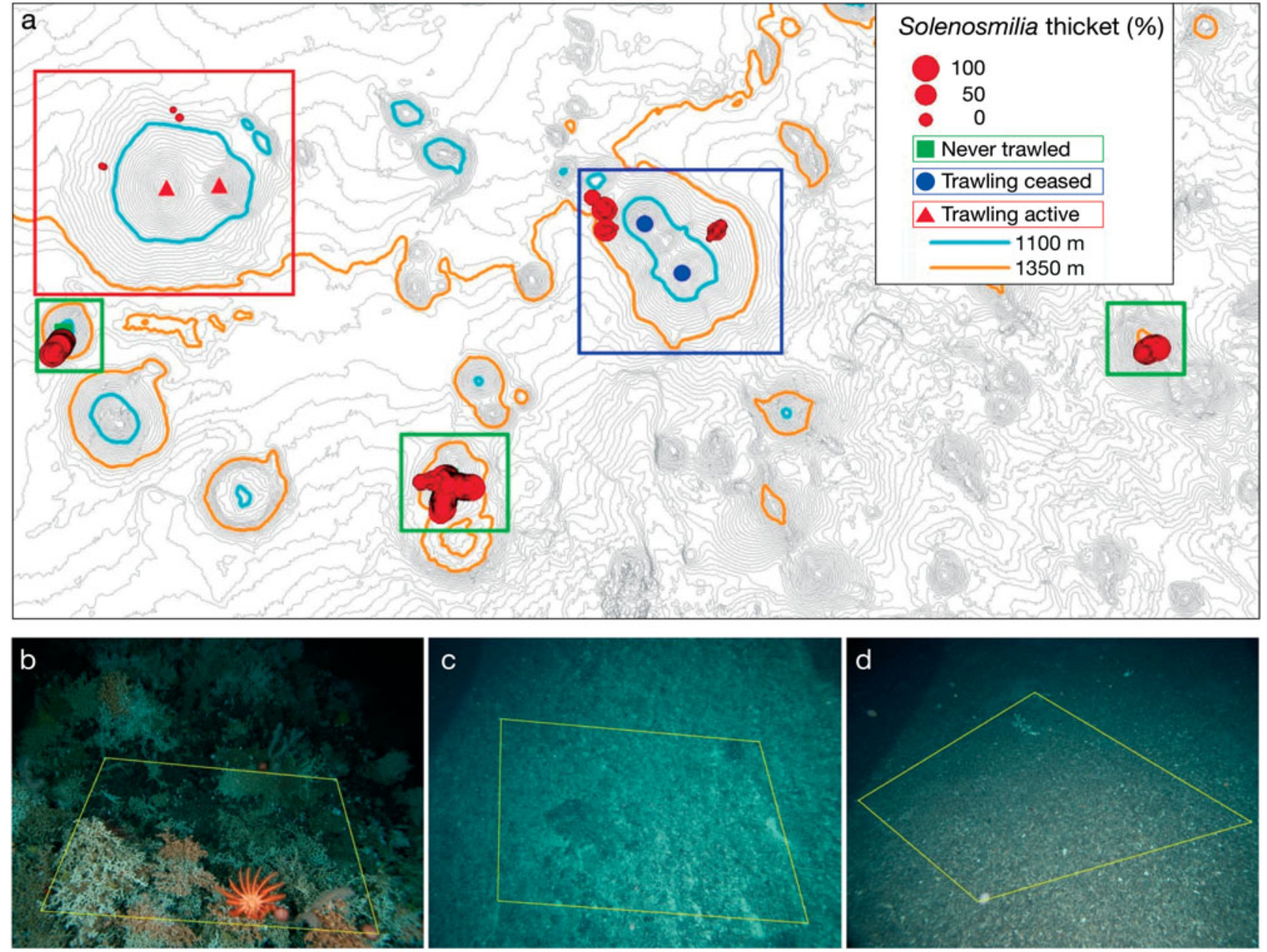

Fig. 4. (a) Graduated bubbles showing the percent cover of Solenosmilia thicket (3-dimensional framework built by live $S$. variabilis and its dead skeletons) on seamounts with differing fishing histories (indicated by symbol and frame colour), and representative images of seamounts (b) that were never trawled, (c) where trawling ceased 5 to 10 yr ago and (d) where trawling is active; yellow outlines delineate measured areas used as virtual quadrats 


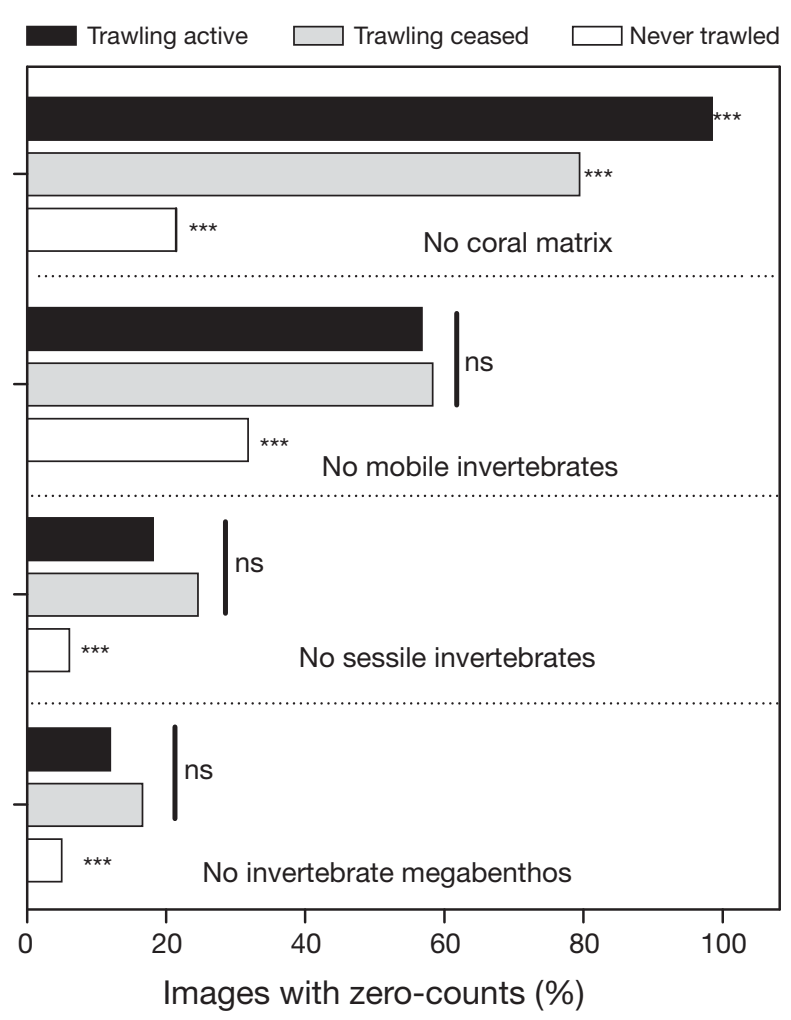

Fig. 5. Comparison of the number of null samples (i.e. images with zero counts for plotted categories) on actively trawled (black), trawling-ceased (grey) and never-trawled seamounts (white). ${ }^{* * *} \mathrm{p}<0.001$; ns: $\mathrm{p}>0.001$

and richness between thickets and barren areas was consistent for sessile and mobile photo-taxa (Table 2). This pattern was reflected in the significantly higher abundance of images without any invertebrate megabenthos (mobile, sessile or combined) on trawled seamounts (active and ceased) where the Solenosmilia thicket was also sparse (Fig. 5). Images with Solenosmilia thicket harboured a greater diversity of megabenthos at a slightly lower evenness (Table 2).

\section{Changes to megabenthic assemblages related to fishing history}

Significantly fewer species at a much reduced density remain in the impoverished assemblages which are typical of seamounts that have been trawled, regardless of whether fishing had effectively ceased 5 to $10 \mathrm{yr}$ ago or is still active (Figs. 6 \& 7). There were significantly fewer photo-taxa per image
$\left(H_{(\mathrm{N}=714)}=188.6, \mathrm{p}<0.001\right)$ and lower values of diversity indices (Hill's N1, $H_{(\mathrm{N}=714)}=161.2, \mathrm{p}<0.001$; Hill's $\left.\mathrm{N} 2, H_{(\mathrm{N}=714)}=199.4, \mathrm{p}<0.001\right)$ in images taken on trawled seamounts. Pairwise post hoc $z$-tests of species richness and diversity showed no significant difference between seamounts where trawling had ceased and those where trawling was still active (photo-taxa per image, $p=0.15$; Hill's N1, $p=0.39$; Hills' N2, $p=0.63$ ), suggesting that recovery of biodiversity is not measurable over 5 to $10 \mathrm{yr}$ in this specific situation. The density of megabenthos was also significantly different between the 3 fishing histories $\left(H_{(\mathrm{N}}=714\right)=150.4, \mathrm{p}<$ 0.001 ), being lowest where trawling had ceased, intermediate on actively trawled seamounts and highest on never-trawled seamounts $(\mathrm{p}<0.001$ for all pairwise post hoc comparisons). Significantly fewer images contained no megafauna on seamounts that had never been trawled compared with more 'zero-catch' images on trawled seamounts (Fig. 5).

Trawling history strongly separated assemblages based on their species composition and abundance (ANOSIM, R = 0.932, p < 0.001; Fig. 8). Megabenthos assemblages on actively-trawled seamounts differed substantially from those on never-trawled seamounts $(\mathrm{R}=0.984, \mathrm{p}=0.005)$, as well as from those where trawling had ceased over the last 5 to $10 \mathrm{yr}(\mathrm{R}=0.926$, $\mathrm{p}=0.029$ ). Assemblages on seamounts where trawling had ceased continued to be widely divergent from those without known fishing activity past and present $(\mathrm{R}=0.895, \mathrm{p}=0.012)$. By summarising the image data by transect we found that the range of the mean fauna density was much greater on never-trawled ( 5 to 20 ind. $\mathrm{m}^{-2}$ ) than on trawled seamounts ( 0 to 5 ind. $\mathrm{m}^{-2}$;

Table 2. Changes in megabenthos density, richness and diversity between stations where Solenosmilia thicket was present compared with areas without the thicket. Measure of the effect size $(\Delta)$ is the ratio of the mean for measurements when Solenosmilia thicket was present $\left(\overline{\mathrm{x}}_{\mathrm{p}}\right)$ divided by the corresponding mean from images without Solenosmilia thicket $\left(\overline{\mathrm{x}}_{\mathrm{a}}\right): \Delta=\left(\overline{\mathrm{x}}_{\mathrm{p}} / \overline{\mathrm{x}}_{\mathrm{a}}\right)$. Species richness: no. phototaxa per image. All contrasts between medians are significant at $\mathrm{p}<0.001$

\begin{tabular}{|lcccc|}
\hline & $\begin{array}{c}\text { Thicket present } \\
(\mathrm{n}=260) \overline{\mathrm{x}}_{\mathrm{p}}\end{array}$ & $\begin{array}{c}\text { Thicket absent } \\
(\mathrm{n}=454) \overline{\mathrm{x}}_{\mathrm{a}}\end{array}$ & $\Delta$ & $\begin{array}{c}\text { Mann-Whitney } \\
\text { U-test }\end{array}$ \\
\hline $\begin{array}{l}\left.\text { Fauna density (ind. } \mathbf{~ m}^{-2}\right) \\
\text { All invertebrate photo-taxa }\end{array}$ & $9.53 \pm 0.55$ & $3.16 \pm 0.28$ & 3.02 & -14.2441 \\
$\quad \begin{array}{l}\text { Sessile invertebrates } \\
\text { Mobile invertebrates }\end{array}$ & $0.77 \pm 0.53$ & $2.89 \pm 0.27$ & 3.03 & -14.2003 \\
Species richness & $0.76 \pm 0.08$ & $0.26 \pm 0.03$ & 2.90 & -9.6470 \\
All invertebrate photo-taxa & $7.76 \pm 0.21$ & $2.51 \pm 0.09$ & 3.09 & -18.2379 \\
Sessile invertebrates & $6.36 \pm 0.18$ & $1.98 \pm 0.08$ & 3.22 & -17.9392 \\
Mobile invertebrates & $1.40 \pm 0.07$ & $0.53 \pm 0.04$ & 2.63 & -10.5932 \\
Species diversity & & & & \\
and evenness & & & & \\
Hill's N1 & $5.02 \pm 0.14$ & $1.87 \pm 0.07$ & 2.68 & -17.1711 \\
Hill's N2 & $3.92 \pm 0.12$ & $1.97 \pm 0.06$ & 1.99 & -14.0238 \\
Evenness (Hill's E5 ratio) & $0.78 \pm 0.01$ & $0.90 \pm 0.00$ & 0.87 & 13.0698 \\
\hline
\end{tabular}




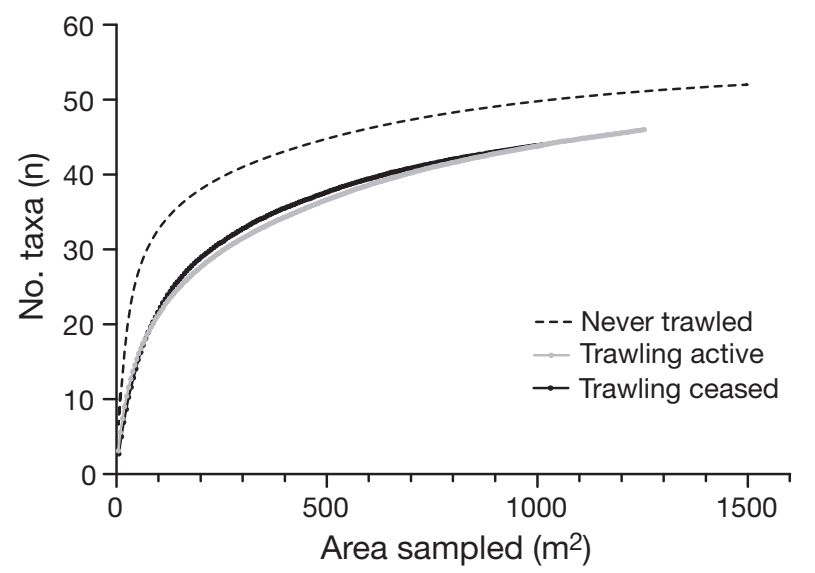

Fig. 6. Contrast in species accumulation curves between images from seamounts that were never trawled (dashed, $\mathrm{n}=280$ ), those where trawling ceased 5 to $10 \mathrm{yr}$ ago (black, $\mathrm{n}=175$ ) and those which continue to be actively trawled (grey, $\mathrm{n}=259$ )

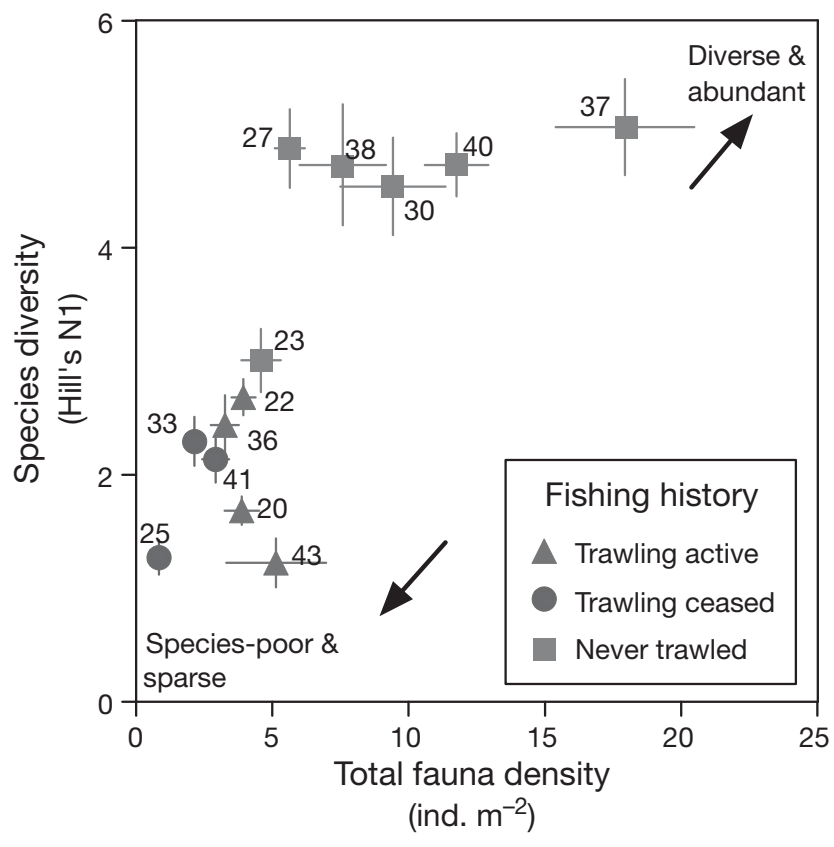

Fig. 7. Differences in species diversity and density between megabenthic invertebrates counted in still images taken at depths between 1100 and $1350 \mathrm{~m}$ on 13 transects on seamounts that were never trawled (6 transects), where trawling ceased 5 to $10 \mathrm{yr}$ ago (3 transects) and where trawling is still active (4 transects) (transect nos. in Table 1).

Data are mean $\pm \mathrm{SE}$

Fig. 7). Transect 23 on never-trawled Hill U stood out for its particularly low mean density and diversity values which were similar to those of trawled seamounts (Fig. 7). Interestingly, this transect was not separated from other transects on never-trawled seamounts based on its community structure (Fig. 8).

Fourteen of the 51 megabenthos photo-taxa contributed $>67 \%$ to the average dissimilarity between groups based on fishing history (Table 3). Ten of these

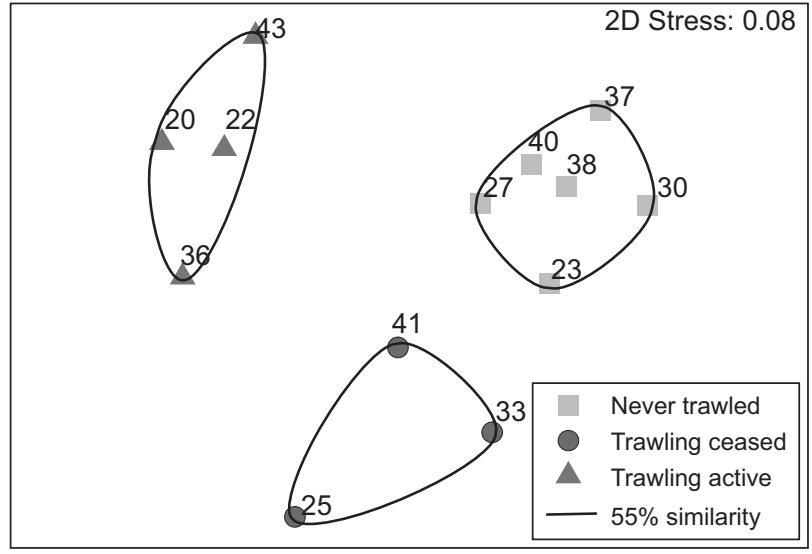

Fig. 8. Non-metric multidimensional scaling ordination of assemblages from transects sampled on seamounts with different histories of known fishing activity (transect nos. in Table 1)

14 photo-taxa - a mix of corals, sponges, echinoderms and squat lobsters - were more abundant on nevertrawled seamounts. The remaining 4 photo-taxa -2 chrysogorgiid corals, a gorgonian coral and hydroids were more abundant on seamounts where trawling continues (Table 3). Assemblages on seamounts where trawling had ceased were distinguished from others by the presence of the hydrocoral Stylaster spp., solitary stony corals, live colonies of the thicket-building Solenosmilia variabilis and encrusting sponges, all of which were intermediate in abundance between nevertrawled and actively trawled seamounts (Table 3).

The small hydrocoral Stylaster spp. contributed most to the overall dissimilarity between never-trawled and actively trawled seamounts, being consistently less abundant at actively trawled ( $\bar{x}=0.37$ ind. $\left.\mathrm{m}^{-2}\right)$ than at never-trawled sites $\left(\bar{X}=2.71\right.$ ind. $\left.\mathrm{m}^{-2}\right)$. It was the most abundant photo-taxon $\left(\bar{x}=1.13\right.$ ind. $\left.\mathrm{m}^{-2}\right)$ observed on seamounts where trawling had ceased in the last decade (Table 3, Fig. 9a). Solitary stony corals contributed most to the difference between seamounts that were never trawled and those where trawling had ceased (Table 3), being densely distributed on never-trawled seamounts $\left(\bar{x}=0.84\right.$ ind. $\left.\mathrm{m}^{-2}\right)$, but very sparse where trawling had ceased ( $\bar{x}=0.02$ ind. $\mathrm{m}^{-2}$; Fig. $\left.9 \mathrm{~b}\right)$. They were not seen on seamounts impacted by ongoing trawling. A whip-like coral, identified as a new genus and new species in the family Chrysogorgiidae (P. Alderslade pers. comm.), was very dense on the actively trawled seamounts $(\bar{x}=$ 2.34 ind. $\mathrm{m}^{-2}$ ), but was also relatively common, although distributed in few high-density patches $(\bar{x}=1.43$ ind. $\mathrm{m}^{-2}$ ) on one never-trawled seamount (Fig. 9c); this coral contributed most $(22 \%)$ to the difference in assemblage structure between seamounts where trawling had ceased and those where it was still active, followed by Stylaster spp. (7\%) and Chrysogorgia spp. (6\%; Table 3). 
Table 3. Summary of photo-taxa contributing substantially to differences in assemblage structure between seamounts of different fishing history, based on similarity percentage analysis. Listed photo-taxa are those which ranked amongst the top 10 in any pairwise comparison between fishing classes; bold: highest mean density across the 3 fishing categories. NT: never trawled; TA: trawling active; TC: trawling ceased

\begin{tabular}{|lccccccc|}
\hline \multirow{2}{*}{$\begin{array}{l}\text { Photo-taxon } \\
\text { Density }\end{array}$} & & \multirow{2}{*}{, ind. $\left.\mathrm{m}^{-2}\right)$} & \multicolumn{3}{c|}{ Contribution to dissimilarity } \\
\cline { 7 - 8 } & NT & TC & TA & NT vs. TA & NT vs. TC & TC vs. TA \\
\hline Chrysogorgiidae & 1.43 & 0.06 & $\mathbf{2 . 3 4}$ & 8.02 & 8.92 & 21.76 \\
new gen. new sp. & & & & & & \\
Stylaster spp. & $\mathbf{2 . 7 1}$ & 1.13 & 0.37 & 9.45 & 7.01 & 6.69 \\
Solenosmilia variabilis & $\mathbf{0 . 8 9}$ & 0.07 & $<0.01$ & 8.14 & 7.00 & 3.81 \\
Encrusting sponges & $\mathbf{0 . 8 8}$ & 0.06 & 0.00 & 8.10 & 7.52 & 2.97 \\
Solitary stony corals & $\mathbf{0 . 8 4}$ & 0.02 & 0.00 & 8.37 & 8.54 & 2.04 \\
Dermechinus horridus & $\mathbf{0 . 3 2}$ & $<0.01$ & 0.08 & 3.18 & 5.18 & 3.31 \\
Alcyonacea type E & 0.01 & 0.11 & $\mathbf{0 . 2 0}$ & 2.85 & 2.79 & 4.69 \\
Chrysogorgia spp. & 0.14 & 0.02 & $\mathbf{0 . 3 5}$ & 2.63 & 2.23 & 6.39 \\
Lumpy sponges & $\mathbf{0 . 1 4}$ & 0.08 & $<0.01$ & 2.96 & 2.27 & 3.12 \\
Primnoidae & $\mathbf{0 . 1 1}$ & $<0.01$ & 0.07 & 2.08 & 2.69 & 3.15 \\
Unstalked crinoids & $\mathbf{0 . 4 7}$ & 0.02 & 0.04 & 4.27 & 5.68 & 1.46 \\
Other hydroids & 0.03 & 0.00 & $\mathbf{0 . 1 4}$ & 2.09 & 1.57 & 5.23 \\
Thouarella spp. & $\mathbf{0 . 3 5}$ & 0.02 & 0.01 & 3.76 & 4.49 & 1.32 \\
Galathaeid & $\mathbf{0 . 1 5}$ & 0.01 & 0.02 & 2.45 & 2.97 & 1.50 \\
\hline
\end{tabular}

\section{DISCUSSION}

\section{Trawling impacts on seamount corals}

Corals are an integral part of the deep megabenthic fauna of many seamounts: they are often abundant, species-rich and form habitats as ecosystem engineers (sensu Jones et al. 1994), including reef-like thickets that create structural habitat complexity for a multitude of invertebrates and fishes (Henry \& Roberts 2007, Rogers et al. 2007, Mortensen et al. 2008). Corals are therefore a key driver of epibenthos diversity on seamounts (Rogers et al. 2007, Mortensen et al. 2008).

The coral Solenosmilia variabilis was the most common, matrix-building species on the seamounts surveyed in the present study. It occurred as long, apparently contiguous patches on 15 untrawled seamounts south of Tasmania at depths shallower than $1400 \mathrm{~m}$, an observation similar to those made on seamounts on the Chatham Rise off New Zealand (Clark and Rowden 2009). In contrast, bare substrata were most common throughout all depth ranges on trawled seamounts. Relatively dense stands of one unbranched, whip-like chrysogorgiid soft-coral attached to bare rock substrata were also observed in patches on trawled seamounts. Solenosmilia thickets were virtually absent from trawled seamounts (as observed in video), except for isolated remnant patches (typically < $10 \mathrm{~m}$ linear distance separated by 100s of m), apparently associated with locally complex topography inaccessible to trawls. Below $1400 \mathrm{~m}$ depth, Koslow et al. (2001) reported a community shift from dense coral thicket to sparse, urchin-dominated assemblages based on observations in isolated still images. We also observed a decline in the abundance of corals below $1300 \mathrm{~m}$ and a shift to other megabenthos (e.g. small sponges and anemones) in continuous video recording (Fig. 2), but did not observe the urchin-dominated assemblages.

All known shallow seamounts (peaks at $\sim 700$ to $1000 \mathrm{~m}$ ) in the region south of Tasmania experienced some degree of bottom-trawling in the initial exploratory phase of the orange roughy fishery between 1988 and 1996 (Koslow et al. 2001). Fishing typically involved flying the trawl net through the water column and over the seamount peak where orange roughy aggregated in $~ 700$ to $1000 \mathrm{~m}$, then herding them into the net as it was towed down to the slope of the seamount, until they were winched up at the base. The shallower peaks were preferentially targeted because fishers found that the catches from deeper peaks had higher proportions of less-favoured dories and sharks (M. Lewis pers. comm.); however, despite the preference for shallower targets, mean fishing depths up to $1400 \mathrm{~m}$ were reported (AFMA unpubl. data). The widespread impact in this depth range therefore makes it difficult to avoid depth becoming a confounding factor in a comparative analysis between trawled and never-trawled seamounts. We addressed this problem by limiting data to the 1100 to $\sim 1400 \mathrm{~m}$ depth stratum which is common to both trawled and never-trawled seamounts. This was possible because technological advances since Koslow et al.'s (2001) original survey now permit each individual photographic image to be accurately geo-located and depthregistered. The chosen depth range is known to include the depth range of living Solenosmilia variabilis thicket in our study area, and is reported as the overlap zone of the general distribution ranges of the shallower stylasterid and scleractinian corals and the deeper alcyonaceans and antipatharians (Rogers et al. 2007). We consistently observed Solenosmilia thickets on peaks and flanks of never-trawled seamounts in this depth range and thus are confident that, apart from anthropogenic disturbance, there is no reason why this habitat should be rare in the 1100 to $1400 \mathrm{~m}$ depth range on the flanks of shallower-peaking seamounts. In fact, large quantities of $S$. variabilis were reported in the bycatch from early days of the Tasmanian seamounts orange roughy fishery (Koslow et al. 2001), strongly suggesting that the absence of this habitat type is a direct conse- 

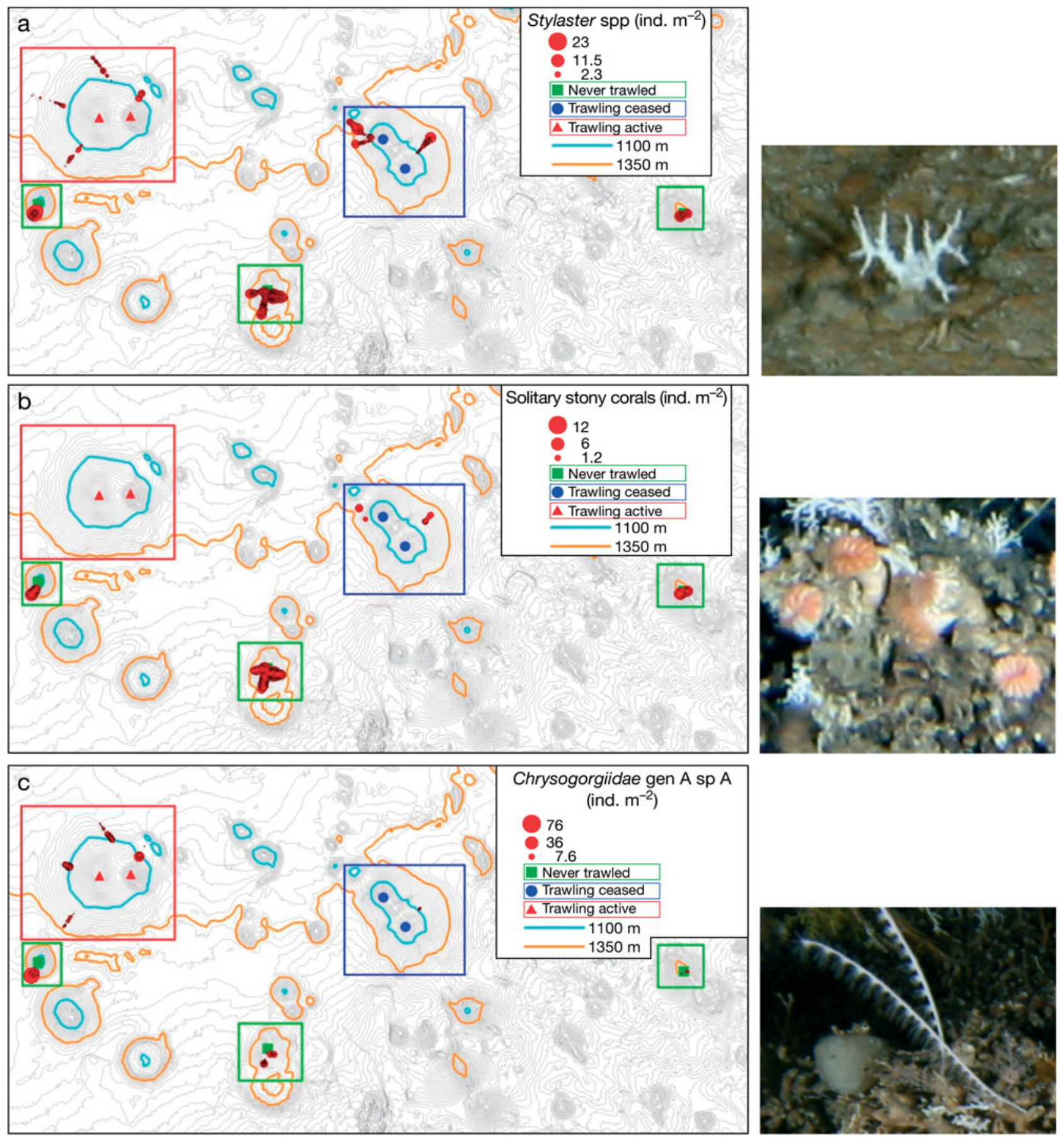

Fig. 9. Density distribution and example images of the 3 photo-taxa contributing most to the differences between seamounts with differing fishing histories: (a) the hydrocoral Stylaster spp., contributed most to the never-trawled vs. trawling-active comparison; (b) solitary stony corals, contributed most to the never-trawled vs. trawling-ceased comparison; and (c) a whip-like new species of the Chrysogorgiidae, contributed most to the trawling-ceased vs. trawling-active comparison

quence of trawling. Despite these clear patterns, and in the absence of any obvious fundamental differences in the physical morphology and environment between seamounts (beyond peak depth and size), we acknowledge that our comparison of benthic megafauna within the same depth range does not exclude the possibility that underlying faunal differences between deep and shallow seamounts may remain undetected.

Corals and the habitat they form are highly vulnerable to removal and mechanical damage by trawl gear 
(Koslow et al. 2001, Clark \& O'Driscoll 2003, Clark \& Koslow 2007, Reed et al. 2007, Clark \& Rowden 2009), and the destructive nature of this type of fishing has been demonstrated in numerous studies (Hall-Spencer et al. 2002, Clark \& Koslow 2007, Reed et al. 2007). The rigid, hard matrix of scleractinian corals such as Solenosmilia variabilis is likely to get crushed by the heavy trawl doors or tangled in the ropes and nets (Clark \& Koslow 2007, Clark \& Rowden 2009), leaving rubble or bare rock substrata behind. Similarly, large branched forms of deepsea gorgonians and black corals are vulnerable to fragmentation and entanglement, as is evident from the successful use of tangle nets in the harvest of precious corals (e.g. Grigg 1993). The higher density of snappedoff bases and detached specimens of these corals on trawled seamounts (Fig. 3b) provides additional evidence for the impact of trawling on the seamount fauna.

We found a 3 -fold increase in megabenthos diversity and density in areas with thickets of frameworkbuilding Solenosmilia variabilis (Table 2). Similarly, Mortensen et al. (2008) reported a 1.6-times higher diversity of megabenthos where stony and erect corals were present on the Mid-Atlantic Ridge; Roberts et al. (2008) also reported consistently higher diversity associated with deep-sea reefs. In the present study, the only corals observed in high densities, apart from Solenosmilia thicket, were stands of a whip-like species of Chrysogorgiidae attached to bare rock on the trawled seamounts; these did not appear to be associated with high densities of other megabenthos. In contrast to erect stands of Chrysogorgiidae or large gorgonian corals, coral thickets or reefs provide different habitats; each supporting different assemblages of associated megabenthic fauna (Rogers et al. 2007). Solenosmilia thicket is a complex framework with large interstitial spaces free of sediments (O'Hara et al. 2008); in contrast, the whip-like chrysogorgiid provides little attachment potential above the seafloor and no matrix structure (Fig. 9c).

Our observations support the earlier conclusion of Koslow et al. (2001) that trawling has major impacts on Tasmanian seamount megabenthos by removing coral habitat, which leads to substantial losses in density, species richness and diversity of the megabenthos. The effect of trawling on megabenthos assemblage structure therefore appears to be a combination of direct removal of vulnerable fauna (as bycatch) and indirect flow-on effects through removal of large, habitat-forming species and accumulated biogenic substratum.

\section{Are changes over time evidence of recovery?}

A decade after trawling was substantially reduced and 5 yr after it had ceased on the Sisters seamounts (Fig. 1), the composition, distribution and abundance of megabenthic communities observed there was distinctly different to that on seamounts that were never trawled. We found no evidence of recovery or regrowth of Solenosmilia thicket and its associated megafauna in the large areas of bare seafloor that appear to have been cleared by trawling. Deep-sea invertebrates, corals in particular, are long-lived and slow growing (e.g. Samadi et al. 2007, Tracey et al. 2007); for example, Corallium secundum colonies of $28 \mathrm{~cm}$ in height were estimated to be $\sim 67$ to 71 yr old (Roark et al. 2006). Preliminary results indicate that Solenosmilia variabilis is also a slow-growing species (R. Thresher pers. comm.). Even in shallow waters, Kaiser et al. (2006) found that soft corals took up to 8 yr to recover from trawling impacts. Collectively, these observations indicate that a decade may be too short a time to detect a measurable recovery of the coral communities.

Where trawling had ceased, the megafaunal assemblage structure and density (but not diversity or evenness) was also significantly different from seamounts that were still actively fished (albeit at substantially reduced rates). Formerly trawled seamounts had intermediate abundances of key photo-taxa which occurred at high densities on never-trawled seamounts, and which were absent or found only at low densities on the actively trawled seamounts (e.g. Solenosmilia variabilis, Stylaster spp., encrusting and lumpy sponges and the sea urchin Dermechinus horridus; Table 3). Given the apparent low growth rate of Solenosmilia variabilis, it is unlikely that the observed patches of thicket on the formerly trawled seamounts represent new growth. Here the thicket-forming coral was observed in low abundance in isolated crevices, behind boulders and near ledges, suggesting they were remnant patches, inaccessible to trawls.

The sponges and sea urchin were closely linked to the presence of the stony coral in individual photographs, suggesting that they are part of the surviving coral habitat. In contrast, Stylaster spp. (one or more species of small hydrocorals) were widely distributed in images from all seamounts, with increasing abundance from actively trawled to trawling-ceased to never-trawled. We interpreted this pattern as early colonisation, possibly initiated by surviving colonies. However, considering that Brooke \& Stone (2005) report deep-sea hydrocorals in the Aleutian Islands have limited potential to recolonise disturbed areas, as they are gonochoristic brooders without gamete synchronisation within single specimens, more detailed studies of these species on the Tasmanian seamounts, including size comparisons, are required to determine the source of recruits to areas damaged by trawls.

Four cnidarian photo-taxa had substantially higher abundance on trawled seamounts (Table 3): hydroids, small corals of the genus Crysogorgia, another small 
octocoral (Alcyonacea type E) and one species from a new genus of a whip-like chrysogorgiid. Dense stands of the whip-like chrysogorgiid were observed on the actively trawled seamounts, suggesting that it may be an early coloniser or competitive dominant where the thicket was removed. However, the densest stand of this species (in 1 individual photograph) was observed in undisturbed Solenosmilia thicket on a never-trawled seamount (z16; Fig. 9c). This species is a relatively small $(<30 \mathrm{~cm})$ unbranched coral that, in life, is quite flexible; thus it is feasible that it passes relatively unharmed under the rollers of a demersal trawl. Stone et al. (2005) reported that sea whips in soft sediment habitats showed no clear difference in densities between trawled and untrawled sites, suggesting they might be resistant to the direct impact of trawls, although individuals in trawled areas were smaller $(20$ to $80 \mathrm{~cm})$ than individuals at untrawled sites $(>80 \mathrm{~cm})$. Eno et al. (2001) described a resistance to direct impact of fishing gears by various species of sea pens and the sea fan Eunicella verrucosa that bend under the pressure wave of settling creels or under the weight of pots. The Chrysogorgia corals observed in greater abundance on the actively trawled seamounts in our study area were similarly small in size and flexible. They had a compact bottle-brush shape, possibly allowing them to pass relatively unharmed under the trawl gear. Both species were also abundant in Solenosmilia thickets on seamounts that were never trawled, supporting the hypothesis that these species are resistant to trawl damage rather than being competitively excluded from the thickets, or being early colonisers. Hydroids, on the other hand, are thought to be relatively fast-growing early colonisers in disturbed habitats (K. GowlettHolmes pers. comm.); they were 5 times more abundant on trawled compared to never-trawled seamounts.

The differences in assemblage structures and megabenthic fauna detected in our data therefore appear to result from some species that survived trawl impact, either by being resistant to trawl damage through small size and great flexibility, or by being protected in natural refugia formed by the rugged topography, or both; some species may also be early colonisers of disturbed areas. The presence of remnant Solenosmilia matrix with live colonies adjacent to cleared areas may facilitate the return of this habitat type over larger areas because this species is capable of asexual budding as well as larval dispersal (Rogers et al. 2007). In addition, Solenosmilia thickets support a diverse fauna (e.g. sponges, solitary corals and ophiuroids) that may also have survived in such topographic refugia. In contrast, where the Solenosmilia matrix was completely removed, recolonisation will largely depend on chance arrival, settlement and recruitment of larvae from more distant sources.

\section{Relevance to conservation}

Our observations and the slow growth of seamount fauna suggest that recovery of the seamount benthos will take many decades, if not longer. Remnant patches of undisturbed fauna and local-scale recruitment processes may have the potential to effect recovery, including preserving local genetic variability and prevent extinction of endemic species. However, assessing and measuring recovery remains a challenge for future research because of differences in, and poor knowledge of, species' lifehistory traits; poorly quantified variation in community structure between individual seamounts; the unknown dependence of recovery on accumulated biogenic habitat; and lack of knowledge of the areas of coral habitat remaining on impacted seamounts. For these reasons, defining an acceptable degree of impact (bycatch and habitat damage) to regulate trawling and justify management actions is problematic.

Ecological characteristics of seamounts relevant to conservation management can be qualitatively assessed using a suite of attributes in an ecological evaluation framework (EEF) (Pitcher \& Bulman 2007, Pitcher et al. 2007). An approach such as this differentiates the biodiversity characteristics and relative vulnerabilities of individual seamounts and avoids weaknesses in current design processes for deep-water reserves that include: (1) 'false homogeneity', where all habitats of a given category (e.g. seamounts) are treated as having equal conservation value (Williams et al. 2009), and (2) failing to prioritise between individual features based on observed or predicted biodiversity values (Schlacher et al. 2009). The value of EEFs for seamount conservation planning, at least for long-lived megabenthos, is clearly demonstrated by depth-related characteristics of seamounts in our study area. The general disappearance of living Solenosmilia thicket at a faunal transition around $1400 \mathrm{~m}$ depth, and the ubiquitous trawl impact on flanks from $\sim 700$ to $>1200$ m depths, means simply that seamounts extending above $1400 \mathrm{~m}$ depth and with complex topography inaccessible to bottom trawling represent the highest priorities for conserving megabenthos. Shoaling of aragonite saturation depths as the ocean acidifies with predicted climate change will reduce the lower depth limit of corals (Roberts et al. 2006, Tittensor et al. 2009), further emphasising the need to conserve shallow seamounts.

Options for operational conservation of seamount megabenthos diversity include spatial management of whole features or clusters (Probert et al. 2007). Regulation of bottom trawling to particular sectors or depth ranges on individual seamounts is technically feasible but impractical to enforce. Alternatively, targeted closures of individual or groups of seamounts while leaving others available for trawling is enforceable and 
provides a balance between sustaining seamount fisheries and conserving seamount biodiversity. This approach has now been implemented in our study area and in the Graveyard complex off New Zealand (Clark \& Rowden 2009) and, together with our findings of long recovery periods following fishing impacts, provides operational examples and evidence to support the efforts of Regional Fisheries Management Organisations to protect vulnerable seamount ecosystems as warranted by the 2006 United Nations General Assembly Resolution 61/105.

Because the impacts of trawling on megabenthos and biogenic habitat are long-lasting, there are unlikely to be measureable performance benefits against management goals for ecosystem recovery in the typically short timeframe of management plans (e.g. the 7-yr span for the Huon Commonwealth Marine Reserve that encompasses part of our study area). In general terms, the conservation measures for seamount ecosystems therefore require a long-term commitment. Management planning needs to be supported by time series (monitoring) data from replicated reference sites. These data need to disentangle the effects of depth and bottom type, and increase our knowledge of the variability and connectivity of megabenthic communities on individual seamounts and within seamount clusters. Such studies would enable more precise and detailed predictions than the one implicit in the present study: that, over time, trawlingceased seamounts should look increasingly like nevertrawled seamounts. Some of these more subtle predictions may be testable in shorter timespans than required for full recovery. Tools including non-extractive and quantitative photography and new genetic techniques are increasingly available for these purposes.

Acknowledgements. Special thanks are due to the staff, officers and crew of the FRV 'Southern Surveyor' who assisted with the collection of our survey data at sea. Funding for the surveys was provided by CSIRO Wealth from Oceans Flagship, and the Australian Government Department of Water, Environment, Heritage and the Arts, with support from Australia's Marine National Facility. Our colleagues A. Butler and C. Bulman provided helpful comments on an earlier version of the manuscript, and reviews by 3 anonymous reviewers enabled us to make many further improvements. The authors are supported through the Commonwealth Environment Facilities (CERF) programme, an Australian Government initiative, and in particular by the CERF Marine Biodiversity Hub and a mini-grant from the Census of Marine Life's Seamounts Program (CenSeam).

\section{LITERATURE CITED}

Anderson OF, Clark MR (2003) Analysis of bycatch in the fishery for orange roughy, Hoplostethus atlanticus, on the South Tasman Rise. Mar Freshw Res 54:643-652

Andrews AH, Cordes EE, Mahoney MM, Munk K, Coale KH, Cailliet GM, Heifetz J (2002) Age, growth and radiometric age validation of a deep-sea, habitat-forming gorgonian (Primnoa resedaeformis) from the Gulf of Alaska. Hydrobiologia 471:101-110

Bax NJ, Tilzey R, Lyle J, Wayte SE, Kloser RJ, Smith ADM (2005) Providing management advice for deep sea fisheries: lessons learnt from Australia's orange roughy fisheries. In Shotton R (ed) Deep Sea 2003. Conference on the Governance and Management of Deep-sea Fisheries. Part 1: conference reports. 1-5 Dec 2003, Queenstown. FAO Fisheries Proceedings No 3/1. FAO, Rome, p 259-272

Brooke S, Stone R (2005) Reproduction of deep-water hydrocorals (family Stylasteridae) from the Aleutian Islands, Alaska. 3rd Int Symp Deep-Sea Corals. Rosenstiel School of Marine and Atmospheric Science, Miami, FL, p 519-532

Clark MR (2001) Are deepwater fisheries sustainable? The example of orange roughy (Hoplostethus atlanticus) in New Zealand. Fish Res 51:123-135

Clark MR, Koslow JA (2007) Impacts of fisheries on seamounts. In: Pitcher TJ, Morato T, Hart PJB, Clark MR, Haggen N, Santos R (eds) Seamounts: ecology, fisheries and conservation. Wiley-Blackwell, Oxford, p 413-441

Clark MR, O'Driscoll RL (2003) Deepwater fisheries and aspects of their impact on seamount habitat in New Zealand. J Northwest Atl Fish Sci 31:441-458

Clark MR, Rowden AA (2009) Effects of deepwater trawling on the macro-invertebrate assemblages of seamounts on the Chatham Rise, New Zealand. Deep-Sea Res I 56: $1540-1554$

Clarke KR (1993) Non-parametric multivariate analyses of changes in community structure. Aust J Ecol 18:117-143

Clarke KR, Gorley RN (2006) PRIMER v6: user manual/tutorial. Primer-E, Plymouth

Eno NC, MacDonald DS, Kinnear JAM, Amos SC and others (2001) Effects of crustacean traps on benthic fauna. ICES J Mar Sci 58:11-20

Freiwald AJH, Fosså SJH, Grehan A, Koslow A, Roberts JM (2004) Cold-water coral reefs: out of sight - no longer out of mind. UNEP-WCMC, Cambridge

Genin A (2004) Bio-physical coupling in the formation of zooplankton and fish aggregations over abrupt topographies. J Mar Syst 50:3-20

> Genin A, Dayton PK, Lonsdale PF, Spiess FN (1986) Corals on seamount peaks provide evidence of current acceleration over deep-sea topography. Nature 322:59-61

Genin A, Haury L, Greenblatt P (1988) Interactions of migrating zooplankton with shallow topography: predation by rockfishes and intensification of patchiness. Deep-Sea Res A 35:151-175

Grigg RW (1993) Precious coral fisheries of Hawaii and the U.S. Pacific Islands. Mar Fish Rev 55:50-60

Hall-Spencer J, Allain V, Fosså SJH (2002) Trawling damage to Northeast Atlantic ancient coral reefs. Proc R Soc Lond B Biol Sci 269:507-511

> Henry LA, Roberts JM (2007) Biodiversity and ecological composition of macrobenthos on cold-water coral mounds and adjacent off-mound habitat in the bathyal Porcupine Seabight, NE Atlantic. Deep-Sea Res I 54:654-672

> Jones CG, Lawton JH, Shachak M (1994) Organisms as ecosystem engineers. Oikos 69:373-386

Kaiser MJ, Collie JS, Hall SJ, Jennings S, Poiner IR (2002) Modification of marine habitats by trawling activities: prognosis and solutions. Fish Fish 3:114-136

Kaiser MJ, Clarke KR, Hinz H, Austen MCV, Somerfield PJ, Karakassis I (2006) Global analysis of response and recovery of benthic biota to fishing. Mar Ecol Prog Ser 311:1-14 
Koslow JA, Boehlert GW, Gordon JDM, Haedrich RL, Lorance P, Parin N (2000) Continental slope and deep-sea fisheries: implications for a fragile ecosystem. ICES J Mar Sci 57:548-557

Koslow JA, Gowlett-Holmes K, Lowry JK, O'Hara T, Poore GCB, Williams A (2001) Seamount benthic macrofauna off southern Tasmania: community structure and impacts of trawling. Mar Ecol Prog Ser 213:111-125

Ludwig JA, Reynolds JF (1988) Statistical ecology: a primer on methods and computing. Wiley-Interscience, New York

McClain CR (2007) Seamounts: identity crisis or split personality? J Biogeogr 34:2001-2008

Mortensen PB, Buhl-Mortensen L, Gordon DC Jr, Fader GBJ, McKeown DL, Fenton DG (2005) Effects of fisheries on deepwater gorgonian corals in the Northeast Channel, Nova Scotia. Am Fish Soc Symp 41:369-382

Mortensen PB, Buhl-Mortensen L, Gebruk AV, Krylova EM (2008) Occurrence of deep-water corals on the MidAtlantic Ridge based on MAR-ECO data. Deep-Sea Res II 55:142-152

O'Hara T, Rowden AA, Williams A (2008) Cold-water coral habitats on seamounts: Do they have a specialist fauna? Divers Distrib 14:925-934

Pitcher TJ, Bulman C (2007) Raiding the larder: a quantitative evaluation framework and trophic signature for seamount food webs. In: Pitcher TJ, Morato T, Hart PJB, Clark MR, Haggen N, Santos R (eds) Seamounts: ecology, fisheries and conservation. Wiley-Blackwell, Oxford, p 282-295

Pitcher TJ, Morato T, Hart PJB, Clark MR, Haggen N, Santos R (eds) (2007) Seamounts: ecology, fisheries and conservation. Wiley-Blackwell, Oxford

Probert PK, McKnight DG, Grove SL (1997) Benthic invertebrate bycatch from a deepwater fishery, Chatham Rise, New Zealand. Aquat Conserv 7:27-40

Probert PK, Christiansen S, Gjerde KM (2007) Management and conservation of seamounts. In: Pitcher TJ, Morato T, Hart PJB, Clark MR, Haggen N, Santos R (eds) Seamounts: ecology, fisheries and conservation. Wiley-Blackwell, Oxford, p 442-475

Reed JK, Koenig CC, Shepard AN (2007) Impacts of bottom trawling on a deep-water Oculina coral ecosystem off Florida. Bull Mar Sci 81:481-496

Roark EB, Guilderson TP, Dunbar RB, Ingram BL (2006) Radiocarbon-based ages and growth rates of Hawaiian deep-sea corals. Mar Ecol Prog Ser 327:1-14

Roberts JM, Wheeler AJ, Freiwald A (2006) Reefs of the deep: the biology and geology of cold-water coral ecosystems. Science 312:543-547

Roberts JM, Henry LA, Long D, Hartley JP (2008) Cord-water coral reef frameworks, megafaunal communities and evi- dence for coral carbonate mounds on the Hatton Bank, north east Atlantic. Facies 54:297-316

Rogers AD (1994) The biology of seamounts. Adv Mar Biol 30:305-350

Rogers AD, Baco A, Griffiths H, Hart T, Hall-Spencer JM (2007) Corals on seamounts. In: Pitcher TJ, Morato T, Hart PJB, Clark MR, Haggen N, Santos R (eds) Seamounts: ecology, fisheries and conservation. Wiley-Blackwell, Oxford, p 141-169

Rowden AA, Clark MR, Wright IC (2005) Physical characterisation and a biologically focused classification of 'seamounts' in the New Zealand region. NZ J Mar Freshw Res 39:1039-1059

Samadi S, Schlacher T, Richer de Forges B (2007) Seamount benthos. In: Pitcher TJ, Morato T, Hart PJB, Clark MR, Haggen N, Santos R (eds) Seamounts: ecology, fisheries and conservation. Wiley-Blackwell, Oxford, p 119-140

Schlacher TA, Williams A, Althaus F, Schlacher-Hoenlinger MA (2009) High-resolution seabed imagery as a tool for biodiversity conservation planning on continental margins. Mar Ecol (in press)

Sherwood OA, Scott DB, Risk MJ (2006) Late Holocene radiocarbon and aspartic acid racemization dating of deep-sea octocorals. Geochim Cosmochim Acta 70:2806-2814

Shortis MR, Seager JW, Williams A, Barker BA, Sherlock M (2008) Using stereo-video for deep water benthic habitat surveys. Mar Technol Soc J 42:28-37

Smith DK, Jordan TH (1988) Seamount statistics in the Pacific Ocean. J Geophys Res 93:2899-2918

Stone RP, Masuda MM, Malachi PW (2005) Effects of bottom trawling on soft-sediment epibenthic communities in the Gulf of Alaska. Am Fish Soc Symp 41:461-476

Tittensor DP, Baco AR, Brewing PE, Clark MR and others (2009) Predicting global habitat suitability for stony corals on seamounts. J Biogeogr 36:1111-1128

Tracey DM, Neil H, Marriott P, Andrews AH, Cailliet GM, Sanchez JA (2007) Deep-sea scleractinian coral age and depth distributions in the northwest Atlantic for the last 225, 000 years. Bull Mar Sci 81:371-391

Watling L, Norse EA (1998) Disturbance of the seabed by mobile fishing gear: a comparison to forest clear cutting. Conserv Biol 12:1180-1197

Wessel P (2007) Seamount characteristics. In: Pitcher TJ, Morato T, Hart PJB, Clark MR, Haggen N, Santos R (eds) Seamounts: ecology, fisheries and conservation. WileyBlackwell, Oxford, p 3-25

Williams A, Bax NJ, Kloser RJ, Althaus F, Barker B, Keith G (2009) Australia's deep-water reserve network: implications of false homogeneity for classifying abiotic surrogates of biodiversity. ICES J Mar Sci 66:214-224 